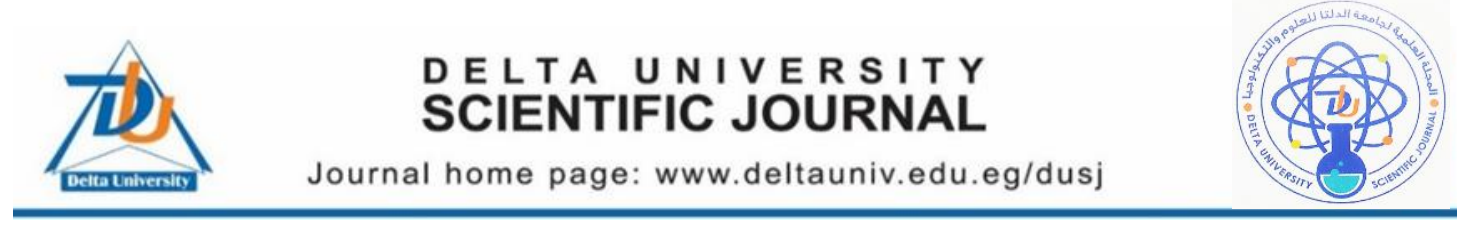

\title{
CONTROL OF EHRLICH TUMOR METASTASIS IN MICE LIVER BY ELECTROMAGNETIC WAVES, CERATES CERATES SNAKE VENOM AND METHOTREXATE
}

\author{
Eman M. Abd El-Kader ${ }^{1}$ AND C. R. Shaker ${ }^{2}$ \\ 1 Department of Pharmacology \& Toxicology, Faculty of Pharmacy, Delta \\ University for Science and Technology, Gamasa, Egypt. \\ ${ }^{2}$ Holding company of biological products and vaccines VACSERA, Cairo, \\ Egypt.
}

\begin{abstract}
The use of chemotherapy for cancer treatment is a successful modality. However, this treatment has its side effects, which limits its applicability. The aim of the present work is a comparative study of side effects of treatment of Cerastes cerastes snake venom and methotrexate on tumor progression in the primary site (thigh of the animal) and in secondary sites (metastasis) formation in the liver of mice. This will be achieved through histological, biochemical and tumor volume investigations on two main groups, (healthy animals and tumor bearing animals) to monitor side effects of the used methodologies on normal tissue and cancerous tissue.A total of 122 mice were used, divided into two groups, "A" and "B". Group A: normal control mice, was given saline $0.2 \mathrm{ml}$. Group B: tumor bearing mice, were subdivided into 3 subgroups: B1: received no treatment; B2: was interperitonealy injected with snake venom $(0.75 \mu \mathrm{g} / \mathrm{g})$; B3: was given $2.8 \mathrm{mg} / \mathrm{kg}$ methotrexate as standard chemotherapy. Histological examination of liver using hematoxylene and eosin (H\& E), as well as blood analysis were performed. Results showed that exposure to ELF- MWs at resonance frequency $4.5 \mathrm{~Hz}, 2 \mathrm{G}$ was quite effective in limiting tumor growth and proliferation, with minimal effect on non- involved tissues. Its use proves to be much safe for treatment of primary tumor site and to secondary sites.
\end{abstract}

Keywords: Ehrlich Tumor Metastasis, Cerates Cerates Snake

\section{Introduction}

Scientific research has been concentrated mainly on cancer and its treatment, most treatment protocols start with surgery followed by chemotherapy and/ or, radiotherapy. Recent research is now targeting tumor cells with

Delta University for Science and Technology

Coastal International Road, Mansoura, Gamasa City, Dakahlia, Egypt

E-mail: dusj@deltauniv.edu.eg

Journal homepage: $\underline{w w w . d e l t a u n i v . e d u . e g / d u s j}$

page |123 
alternative ways using natural products or changing the radiation protocol by using electromagnetic waves at a certain resonance frequency, aiming to decrease the hazards of chemotherapy and radiotherapy on healthy tissues.

The electromagnetic wave is a transverse wave. It has two components; an electric field (E), which oscillates sinusoidal in time, and space, and a magnetic field (B), which oscillates in a perpendicular plane with the same frequency. The electric field is always perpendicular to the magnetic field (Jackson, 1962).

$4.5 \mathrm{~Hz}$ QAMW waves are very promising for the treatment of tumors either in primary site state and/or as a preventive agent for metastasis formation in the secondary site (liver, kidney and spleen) (Fadel et al., 2010).

It is verified that Ehrlich tumors implanted in female mice exposed to $4.5 \mathrm{~Hz}$ square amplitude modulated waves (QAMW) at a rate of $1 \mathrm{~h}$ daily for a period of 3 weeks showed inhibited tumor growth and increased animal survival (Fadel et al., 2003).

Materials and Methods Ehrlich ascites tumor

The tumor was prepared in the National Cancer Institute (NCI), Cairo University, Egypt, maintained in Swiss albino mice in the ascitic form. Tumor cells were collected by aspiration with Pasteur pipette. A suspension of $1 \times 10^{6}$ cells $/ \mathrm{ml}$ was prepared. The animals were injected intramuscularly into the left flank with $0.2 \mathrm{ml}$ of this suspension.

\section{Animals}

Female balb/c mice of average weight $18-20 \mathrm{~g}$ each and of about 5 weeks age were utilized. Animals were housed under normal environmental conditions of temperature $\left(25-30^{\circ} \mathrm{c}\right)$ and humidity $60 \%$. Food and water were provided $a d$ Libitum. The animals were divided into two main subsets of experiments namely $\mathrm{A}$ and $\mathrm{B}, 6-8$ animals were taken from each group as sample for biochemical and histological examinations.

Subset A: were used as control and divided into 2 equal subgroups as follows: $A_{1}$ was intraperitonealy injected with $0.2 \mathrm{ml}$ saline, $\mathrm{A}_{2}$ was whole body exposed to $4.5 \mathrm{~Hz}$ square wave magnetic field of intensity 2 Gauss for a period of 7 days (d) at a rate of $2 \mathrm{~h} / \mathrm{d}$. Subset B: mice were IM injected in the thigh with $0.2 \mathrm{ml}$ Ehrlich tumor suspension and divided into 3 equal subgroups as follows $\mathrm{B}_{1}$ received no treatment till day $23(\mathrm{PI}), \mathrm{B}_{2}$ was whole body exposed to $4.5 \mathrm{~Hz}$ square wave magnetic field at day 15 PI for a period of 7 days at a rate of $2 \mathrm{~h} / \mathrm{d}$ and $\mathrm{B}_{3}$ was interperitonealy injected with methotrexate starting at day 15 PI every other day till day 23 PI in a dose of 2.8 $\mathrm{mg} / \mathrm{kg}$.

Magnetic field exposure system

A power square wave generator was manufactured at the Electronics Workshop in Faculty of Science. Cairo University, Egypt. This generator can produce square wave currents from 0-5 Ampere (A) in the frequency range 010 Kilo Hertz (KHz) (Fadel, 2003). The

Delta University for Science and Technology

Coastal International Road, Mansoura, Gamasa City, Dakahlia, Egypt

E-mail: dusj@deltauniv.edu.eg

Journal homepage: www.deltauniv.edu.eg/dusj 
generator is controlled by computer soft ware with interface.

\section{Chemicals}

Glucose, cholesterol and albumin Kits were obtained from LINEAR CHEMICALS, S.L, Spain. Methotrexate used as parental form and is manufactured and purchased by EBEWE pharma.

\section{Liver Histology}

Liver was dissected and kept in formaldehyde $10 \%$ for histological examination. From each animal the liver was trimmed then fixed in formalin $10 \%$, washed in water then in ascending grades of alcohol (for dehydration). Tissues were cleared in xylol, embedded in soft then hard paraffin to form "blocks". Tissue sections were cut from the blocks at $5 \mathrm{~mm}$ thickness using microtome. Sections were mounted on glass slides, stained using standard "Hematoxylene and Eosin" staining procedure (Culling, 1974). Sections were then examined using Olympus (500) microscope attached to image analysis computerized system, magnification 200, 400 and 1000.

Biochemical measurements

Animals were fasted for $12 \mathrm{~h}$ before sampling, anesthetized by ether, and then blood samples were withdrawn from the heart. Blood samples were centrifuged at $3000 \mathrm{rpm}$ for $5 \mathrm{~min}$. and serum was separated in clean sterile Eppendorf tubes. Serum glucose, cholesterol and albumin levels were measured according to Young, (2000).
Biochemical analysis concentration was automatically calculated by slim spectrophotometer (SEAC Company) at the wavelength recommended in the kit.

Cell counter Danam manufactured in France and provided by LAB Top Company was used for determination of total and differential WBC count. It was represented by lymphocyte \%, monocyte $\%$ and granulocyte $\%$. Differential, total WBC count, and glucose level were measured at the same day of sampling.

Determination of tumor size

The tumor size volume (V) of the thigh (Ning et al., 1994) was calculated from the measured values of the tumor dimensions ( $a, b$ and $\mathrm{c}$ ) everyday starting day 10 PI till the end of experiment. The volume of tumor was calculated according to the following relation:

Where

$$
\mathrm{V}=\mathrm{abcp} / 6
$$

$\mathrm{V}=$ volume of tumor

$\mathrm{a}=$ length

$\mathrm{b}=$ width

$\mathrm{c}=$ height of the tumor.

$\mathrm{p}=22 / 7$

The measurements were done by vernier caliber within $\pm 0.05 \mathrm{~mm}$.

Statistical analysis:

All data were expressed as the mean \pm standard error of mean. Data were subjected to one way ANOVA followed by Tukey Kramer multiple comparison test using Graphpad Instat; version 2004, Purdue University, Indiana, USA. 
$\mathrm{P}<0.05$ was used as criterion for Results significance.

Histological study of liver of Nontumor bearing animals

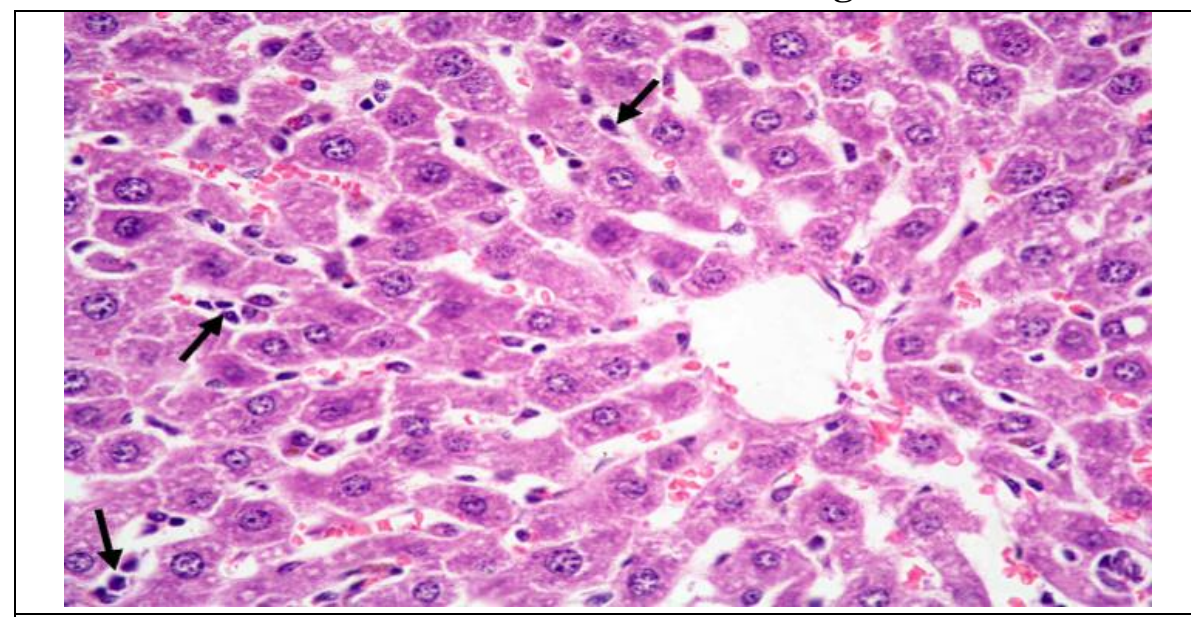

Figure (1a) A photographic cross section for a normal liver shows clear arrangement of the classic hepatic lobules, with cords of hepatocytes radiating around the central veins, enclosing sinusoids in between the hepatic cords are observed. Hepatocytes are seen polygonal, acidophilic with central vesicular nuclei. Kupffer cells are shown among the sinusoidal lining(magnification $\times 400$ ).

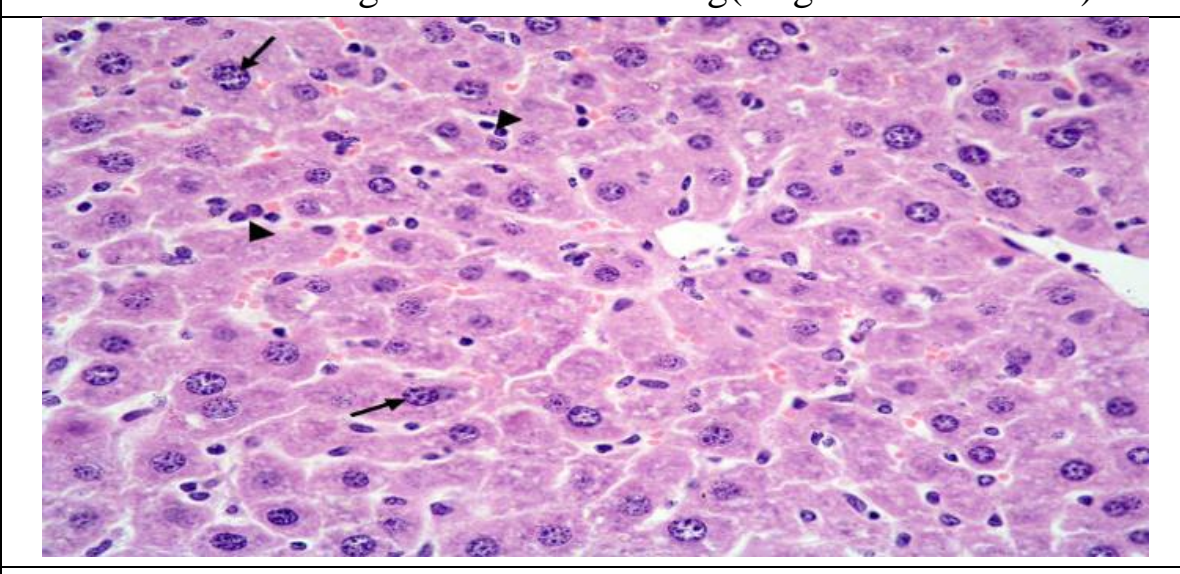

Figure (1b) liver section of group $\mathrm{A}_{1}$ After exposure of whole body of normal mice for magnetic waves $(4.5 \mathrm{~Hz})$ hepatocytes appeared normal with marked increase of Kupffer cells lining the sinusoids.

Nuclei of numerous hepatocytes exhibited many nucleoli(magnification $\times 400$ ).

Delta University for Science and Technology

Coastal International Road, Mansoura, Gamasa City, Dakahlia, Egypt

E-mail: dusj@deltauniv.edu.eg

Journal homepage: www.deltauniv.edu.eg/dusj 


\section{Histological study of liver of tumor bearing animals}

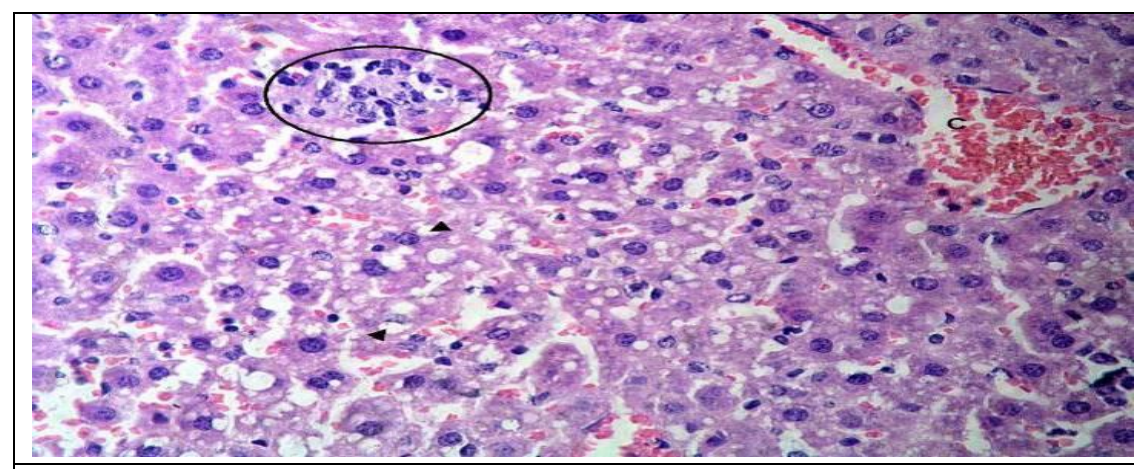

Figure (2a) Liver section of control tumor bearing mice .It is noticed that scattered aggregates of malignant or atypical cells are present in several areas within the liver distributing the normal architecture. Kupffer cells were numerous. Malignant cells showed marked disturbance of nuclear / cytoplasm ratio and nuclear polymorphism. Some degenerated hepatocytes exhibited fragmentation of their nuclei as well as margination of their chromatin .

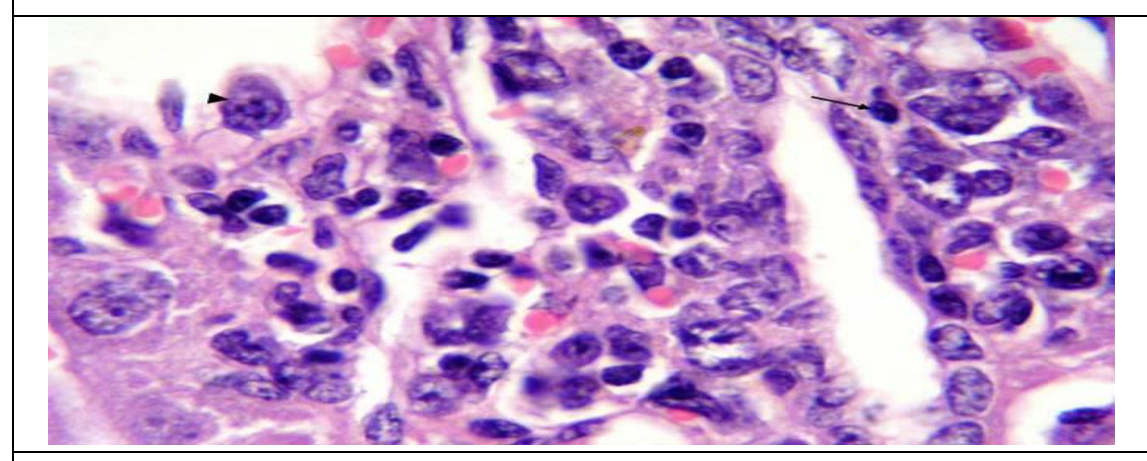

Figure (2b) Tumor-bearing mice exposed to magnetic wave $(4.5 \mathrm{~Hz})$ showed mild affection of hepatocytes but with marked increase in Kupffer cells in many areas. Malignant cellular aggregates showed marked apoptotic changes with some giant hyper chromatic nuclei. Numerous nucleoli were seen in many hepatocytes with very numerous Kupffer cells 


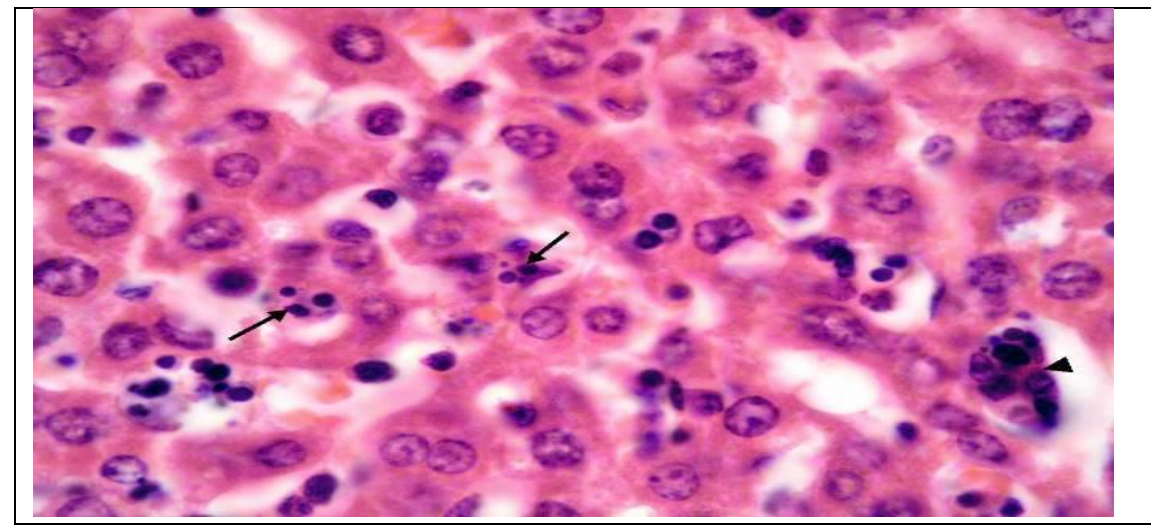

Figure (2c) Liver section of tumor bearing mice received methotrexate $(2.8 \mathrm{mg} / \mathrm{Kg})$ showes loss of hepatic architecture with numerous apoptotic cells. The central zone of the lobule showed marked vacuolations as well as the peripheral zone with marked lymphatic congestion. Apoptosis of the tumor cells was marked and many giant cells were seen

\section{Biochemical findings}

Table (1) Effect of magnetic waves $(4.5 \mathrm{~Hz})$ on total leukocytes, lymphocyte \%, monocyte $\%$ and granulocytes $\%$ in normal mice

\begin{tabular}{|c|c|c|c|c|}
\hline Group & $\begin{array}{c}\text { Total } \\
\text { leukocyte } \\
\text { count } \\
\left(\mathbf{n o} / \mathbf{m m}^{\mathbf{3}}\right)\end{array}$ & $\begin{array}{c}\text { Lymphocytes } \\
(\%)\end{array}$ & $\begin{array}{c}\text { Monocyte } \\
(\%)\end{array}$ & $\begin{array}{c}\text { Granulocytes } \\
(\%)\end{array}$ \\
\hline $\begin{array}{c}\text { Control } \\
(0.2 \mathrm{ml} \text { saline })\end{array}$ & $\mathbf{1 2 4 3 3 \pm \mathbf { 1 7 0 8 }}$ & $\mathbf{8 7 . 7} \pm \mathbf{1 . 7}$ & $\mathbf{5 . 9} \pm \mathbf{0 . 8}$ & $\mathbf{4 . 9} \pm \mathbf{0 . 8}$ \\
\hline $\begin{array}{c}\text { Magnetic field } \\
(4.5 \mathrm{~Hz} \text { 2hrs/day } \\
\text { for 7 days })\end{array}$ & $\mathbf{1 1 5 4 3} \pm \mathbf{1 3 5 2}$ & $\mathbf{7 8} \pm \mathbf{4 . 2}$ & $* \mathbf{1 2 . 6} \pm \mathbf{2 . 4}$ & $* \mathbf{1 2 . 2} \pm \mathbf{2}$ \\
\hline
\end{tabular}

Data are represented as mean \pm standard error.

Each value represents a mean value of 6-7 samples.

*Significantly different from control group

Delta University for Science and Technology

Coastal International Road, Mansoura, Gamasa City, Dakahlia, Egypt

E-mail: dusj@deltauniv.edu.eg

Journal homepage: www.deltauniv.edu.eg/dusj 
Table (2) Effect of magnetic wave $(4.5 \mathrm{~Hz})$ on serum glucose, Cholesterol and Albumin levels in normal mice

\begin{tabular}{|c|c|c|c|}
\hline Group & $\begin{array}{c}\text { Glucose } \\
\text { concentration mg/dl }\end{array}$ & $\begin{array}{c}\text { Cholesterol } \\
\text { concentration } \\
\text { mg/dl }\end{array}$ & $\begin{array}{c}\text { Albumin } \\
\text { concentration } \\
\text { g/dl }\end{array}$ \\
\hline $\begin{array}{c}\text { Control }(0.2 \mathrm{ml} \\
\text { saline })\end{array}$ & $120.3 \pm 30.3$ & $81.2 \pm 4.6$ & $3.5 \pm 0.2$ \\
\hline $\begin{array}{c}\text { Magnetic field (4.5 } \\
\mathrm{Hz} 2 \mathrm{hrs} / \text { day for } 7 \\
\text { days) }\end{array}$ & $* 89.6 \pm 21$ & $* 62.6 \pm 5.2$ & $3.1 \pm 0.2$ \\
\hline
\end{tabular}

Data are represented as mean \pm standard error.

Each value represents a mean value of 6-7 samples.

*Significantly different from control group

Table (3) Effect of magnetic wave $(4.5 \mathrm{~Hz})$, methotrexate $(2.8 \mathrm{mg} / \mathrm{Kg})$, on total leukocytes, lymphocyte \%, monocyte\% and granulocyte \% on normal and tumor bearing mice

\begin{tabular}{|c|c|c|c|c|}
\hline Group & $\begin{array}{c}\text { Total } \\
\text { leukocyte } \\
\text { count } / \mathbf{m m}^{3}\end{array}$ & $\begin{array}{c}\text { Lymphocyte } \\
\%\end{array}$ & Monocyte \% & $\begin{array}{c}\text { Granulocyte } \\
\%\end{array}$ \\
\hline $\begin{array}{c}\text { Control } \\
(0.2 \mathrm{ml} \text { saline })\end{array}$ & $12433 \pm 1708$ & $87.7 \pm 1.7$ & $5.9 \pm 0.8$ & $4.9 \pm 0.8$ \\
\hline $\begin{array}{c}\text { Control } \\
\text { tumor bearing } \\
\text { mice }\end{array}$ & $9280 \pm 1333$ & $66.6 \pm 5.9$ & $22.3 \pm 1.8$ & $15.8 \pm 2.2$ \\
\hline $\begin{array}{c}\text { Magnetic field } \\
\text { (4.5 Hz } \\
\text { 2hrs/day for } 7 \\
\text { days) }\end{array}$ & $14667 * \pm 990$ & $71.3 \pm 4.9$ & $17.3 * \pm 1.9$ & $10.8 \pm 2.2$ \\
\hline $\begin{array}{c}\text { Methotrexate } \\
(2.8 \text { mg/Kg) }\end{array}$ & $13060 * \pm 2310$ & $81.4 \pm 2.7$ & $13.1 * \pm 1.6$ & $8.9 \pm 1.4$ \\
\hline
\end{tabular}

Data are represented as mean \pm standard error.

Each value represents a mean value of 6-7 samples.

* Significantly different from control group

Delta University for Science and Technology

Coastal International Road, Mansoura, Gamasa City, Dakahlia, Egypt

E-mail: dusj@deltauniv.edu.eg

Journal homepage: $\underline{w w w . d e l t a u n i v . e d u . e g / d u s j}$ 


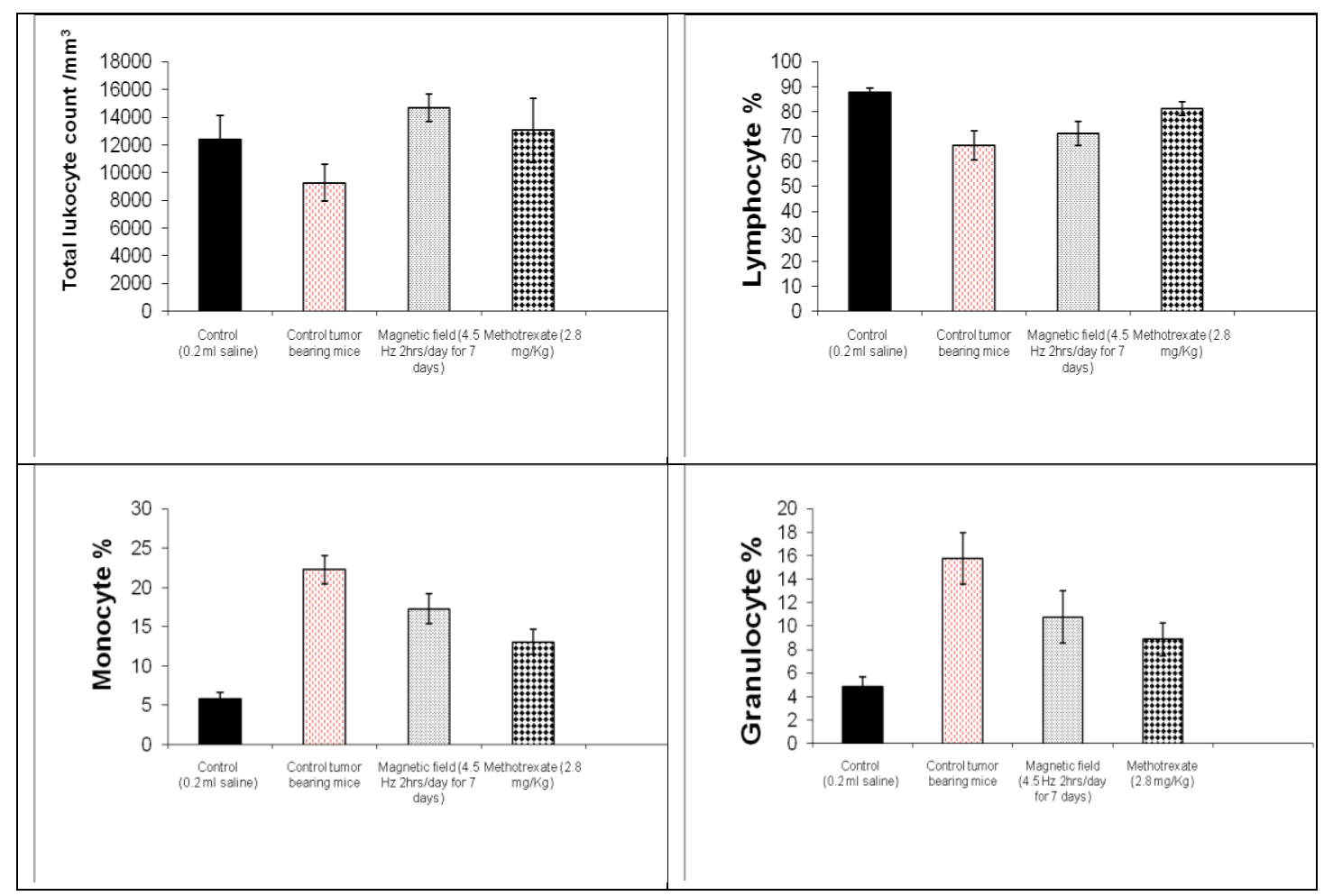

Figure (3) Effect of magnetic wave $(4.5 \mathrm{~Hz})$, and methotrexate $(2.8 \mathrm{mg} / \mathrm{Kg})$, on total leukocytes, lymphocyte \%, monocyte \% and granulocytes \% on tumor bearing mice

Data are represented as mean \pm standard error.

Each value represents a mean value of 6-7 samples.

*Significantly different from control group

Table (4) Effect of magnetic wave $(4.5 \mathrm{~Hz})$, and methotrexate $(2.8 \mathrm{mg} / \mathrm{Kg})$ on serum glucose, Cholesterol and Albumin levels in normal and tumor bearing mice

\begin{tabular}{|c|c|c|c|}
\hline Group & $\begin{array}{c}\text { Glucose } \\
\text { concentration } \\
\mathrm{mg} / \mathrm{dl}\end{array}$ & $\begin{array}{c}\text { Cholesterol } \\
\text { concentration } \\
\mathrm{mg} / \mathrm{dl}\end{array}$ & $\begin{array}{c}\text { Albumin } \\
\text { concentration } \\
\mathrm{g} / \mathrm{dl}\end{array}$ \\
\hline Control (0.2 ml saline) & $\mathbf{1 2 0 . 3} \pm \mathbf{3 0 . 3}$ & $\mathbf{8 1 . 2} \pm \mathbf{4 . 6}$ & $\mathbf{3 . 5} \pm \mathbf{0 . 2}$ \\
\hline Control tumor bearing mice & $\mathbf{1 2 0 . 3} \pm \mathbf{3 0 . 3}$ & $\mathbf{7 9 . 4} \pm \mathbf{8 . 5}$ & $\mathbf{2 . 5} \pm \mathbf{0 . 2}$ \\
\hline $\begin{array}{c}\text { Magnetic field (4.5 Hz } \\
\text { 2hrs/day for 7 days) }\end{array}$ & $\mathbf{1 3 1} \pm \mathbf{1 9 . 5}$ & $\mathbf{8 6 . 9} \pm \mathbf{4 . 3}$ & $\mathbf{3 . 0 \pm 0 . 3}$ \\
\hline Methotrexate (2.8 $\mathbf{~ m g / K g ) ~}$ & $\mathbf{1 2 3 . 3} \pm \mathbf{1 6}$ & $\mathbf{7 6 . 4} \pm \mathbf{5}$ & $\mathbf{3 . 2 \pm 0 . 3}$ \\
\hline
\end{tabular}

Data are represented as mean \pm standard error.

Each value represents a mean value of 6-7 samples.

Delta University for Science and Technology

Coastal International Road, Mansoura, Gamasa City, Dakahlia, Egypt

E-mail: dusj@deltauniv.edu.eg

Journal homepage: $\underline{w w w . d e l t a u n i v . e d u . e g / d u s j}$ 


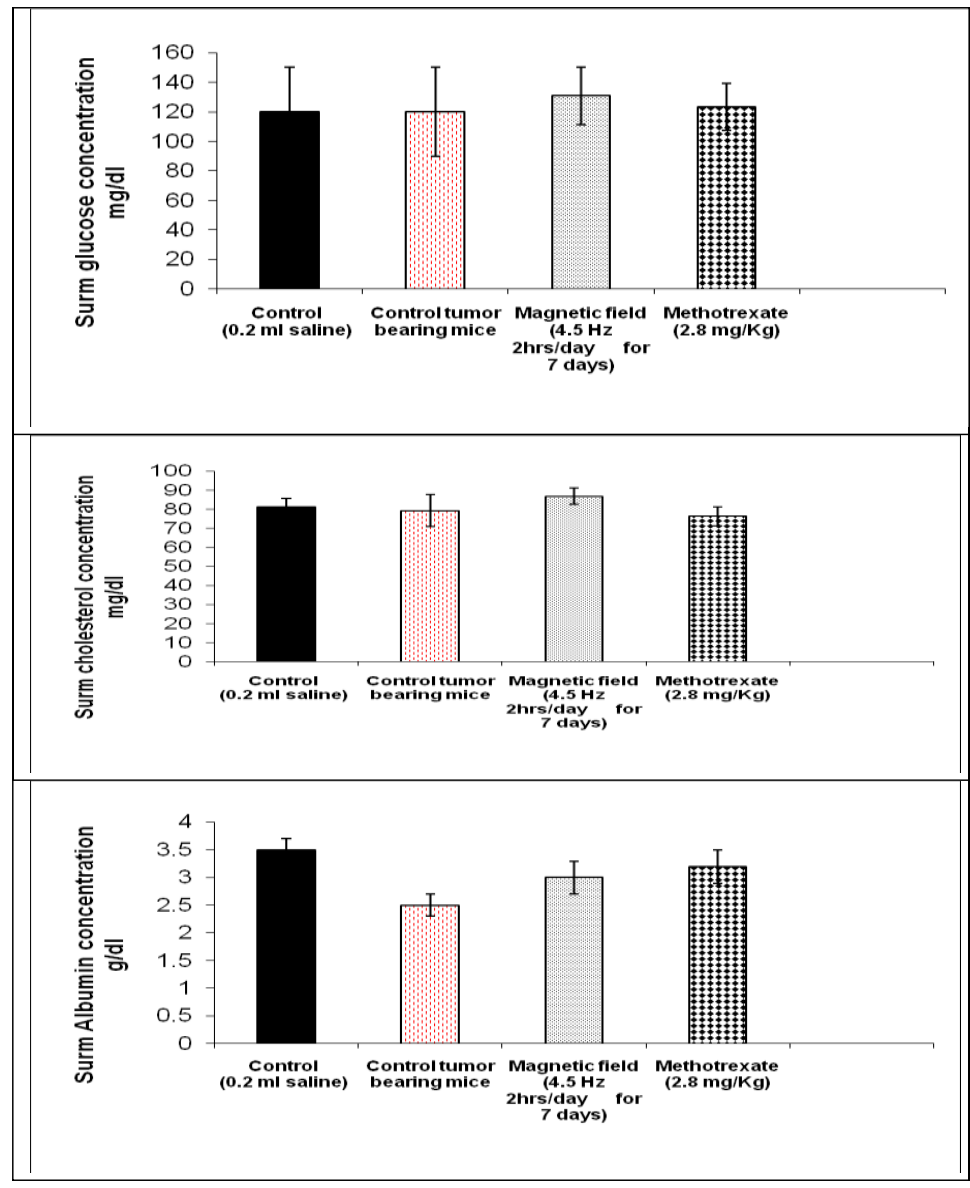

Figure (4) Effect of magnetic wave $(4.5 \mathrm{~Hz})$, and methotrexate $(2.8 \mathrm{mg} / \mathrm{Kg})$ on serum glucose, Cholesterol and Albumin levels in tumor bearing mice Data are represented as mean \pm standard error.

Each value represents a mean value of 6-7 samples.

Table (5): Effect of magnetic field $(4.5 \mathrm{~Hz})$ and methotrexate $(2.8 \mathrm{mg} / \mathrm{Kg})$ on tumor volume size $\mathbf{~ m m}^{3}$.

\begin{tabular}{|l|c|}
\hline \multicolumn{1}{|c|}{ Group } & Tumor Volume size \\
& $\mathbf{m m 3}$ \\
\hline Control tumor bearing mice & $\mathbf{0 . 8 0 8} \pm \mathbf{0 . 1}$ \\
\hline Magnetic field $(4.5 \mathrm{~Hz} 2 \mathrm{hrs} /$ day for 7 days $)$ & $* \mathbf{0 . 3 7 3} \pm \mathbf{0 . 0 4}$ \\
\hline Methotrexate $(2.8 \mathrm{mg} / \mathrm{Kg})$ & $* \mathbf{0 . 3 5 7 \pm 0 . 0 4}$ \\
\hline
\end{tabular}

Delta University for Science and Technology

Coastal International Road, Mansoura, Gamasa City, Dakahlia, Egypt

E-mail: dusj@deltauniv.edu.eg

Journal homepage: $\underline{w w w . d e l t a u n i v . e d u . e g / d u s j}$ 


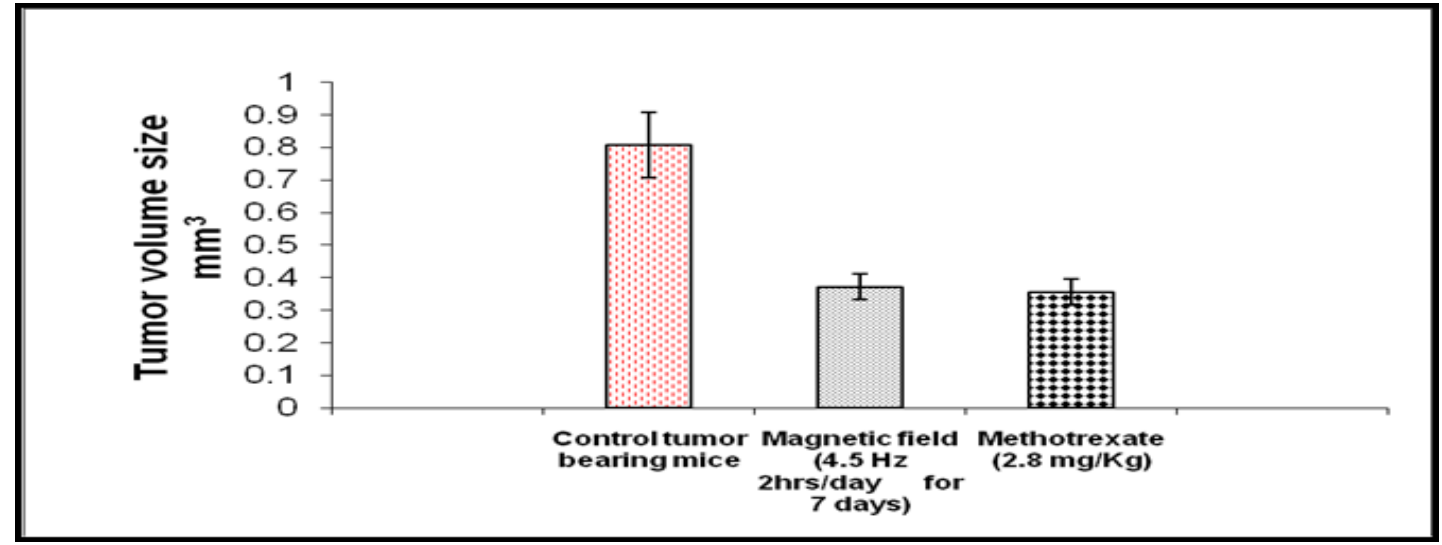

Figure (5) Effect of magnetic wave $(4.5 \mathrm{~Hz})$ and methotrexate $(2.8 \mathrm{mg} / \mathrm{Kg})$ on tumor volume size $\mathbf{~ m m}^{3}$.

Data are represented as mean \pm standard error.

Each value represents a mean value obtained from 14 animals

*Significantly different from control group.

\section{Discussion}

The data recorded in the control group indicated that no changes in the histological patterns of sections of the liver of mice injected with saline.

Whole body exposure of normal animals to $4.5 \mathrm{~Hz}, 2 \mathrm{G}$ magnetic waves resulted into formation of hepatocytes with multiple nucleoli. One may not be able to criticize whether these changes can be considered as a primary step for tumor formation (Domenico and Sergio, 2009) /or just an increase in response of internal activity of hepatocytes to the influence of magnetic field. The first reasoning needs more investigation, including determination of liver tumor markers. This is a probable interpretation of incidence of cancer as a result of exposure to ELF magnetic waves. This is in accord with the findings of occupational study of Gerald et al., (2005) that reported an increasing risk of brain tumor and leukemia for children born close to or at a distance less than 600 meters from power lines. They found that epidemiological exposures to magnetic fields higher than $0.3 \mu$ Tesla ( $3 \mathrm{mG}$ ) cause toxic and carcinogenic effects (Kheifets et al., 2009). All these epidemiological studies were concerned with sine wave magnetic fields of frequencies $50 \mathrm{~Hz}$ or $60 \mathrm{~Hz}$ generated from power lines (Feytching et al., 2005). Moreover, the volume of these developed hepatocytes is similar to normal, as compared with malignant hepatocytes, which are usually smaller in size, and more easily stainable (Turler et al., 2000). The first reasoning is a very important point for future research since it will help scientists to criticize whether exposure to magnetic field can be a detrimental of malignancy or enhanced regenerative process (Behari et al., 2010). One may state that the effect of ELF (extremely

Delta University for Science and Technology

Coastal International Road, Mansoura, Gamasa City, Dakahlia, Egypt

E-mail: dusj@deltauniv.edu.eg

Journal homepage: www.deltauniv.edu.eg/dusj 
low frequency) magnetic waves on biological cells is the generation of induced electric currents from ionic movements (Feytching et al; 2005). These biocurrents will generate bioelectric potential in the cells, which will interfere with its running metabolic process (Hashish et al; 2008). Therefore, one may find that ELF magnetic wave can have two effects: either an increase of metabolic activities within the cells, and/or changing or stopping these activities. The first reasoning is a rationale medical treatment based on magnetotherapy (Newell et al., 2000). While the later reasoning supports the new findings of toxicity of ELF magnetic fields (Behari et al., 2010). The frequency and form of the magnetic wave used in the present work is $4.5 \mathrm{~Hz}$ and its shape was square. These waves induce electric currents and waves inside the treated tissue, which inhibit Ehrlich tumor growth (Fadel, 2005 and 2010). At this frequency the applied induced electromagnetic waves inside the tissues cause destructive interference with the metabolic bioelectromagnetic waves generated during malignant cellular division, which affects the ionic motions evolved in the process (Fadel, 1998). Moreover, epidemiological studies include cases of intrauterine children and newly born children who were in continuous exposure to the magnetic field (Feytching et al., 2005), however in the present investigation, treatment of tumors by magnetic waves in adult animals continued for a limited period of one week at a rate of $2 \mathrm{~h} /$ day.
Significant decrease of serum glucose level was observed in normal animals exposed to $4.5 \mathrm{~Hz}, 2 \mathrm{G}$ magnetic field. The significant decrease of glucose level in blood serum exposed to the magnetic field, indicates a high consumption rate of glucose in order to provide energy to those injured cells and to enhance the repair mechanism (Tu and Giltner, 1974). Significant decrease of serum glucose level was also observed in normal animals exposed to $4.5 \mathrm{~Hz}, 2 \mathrm{G}$ magnetic field in contrary with these results are the findings of Elferchichi et al., (2010) who used static magnetic field on rats $1 \mathrm{hr} /$ day for 15 consecutive days which displayed increase in both plasma glucose level and cholesterol level this may be due to different animal species and different type of magnetic field. In this study significant increase in granulocyte \% was observed and nonsignificant difference in total leukocyte and lymphocyte in normal mice exposed to magnetic field. Further support to the present results was the finding of Hashish et al., (2008) using static magnetic field and extremely low frequency electromagnetic field for whole body exposure in mice, in addition of the results of Cakir et al; (2009) using ELF-EMF $50 \mathrm{~Hz}$ on rats that were exposed to EMF for 50 .The increase in granulocyte $\%$ indicates that there is relation between exposure of extremely low frequency electromagnetic field and the oxidative stress through distressing redox balance leading to physiological disturbances Hashish et al., (2008). The tumor bearing mice were concerned with the

Delta University for Science and Technology

Coastal International Road, Mansoura, Gamasa City, Dakahlia, Egypt

E-mail: dusj@deltauniv.edu.eg

Journal homepage: $\underline{w w w . d e l t a u n i v . e d u . e g / d u s j}$

page |133 
effects of chemotherapy (Methotrexate) and $4.5 \mathrm{~Hz}, 2 \mathrm{G}$ magnetic waves on Ehrlich tumor implanted in the thigh (primary site) and in the liver (secondary site)metastasis. These treatments were consequently followed by investigation of tumor growth at the primary site (thigh) and histological examination of liver sections as a secondary site (metastasis), in addition to estimation of some biochemical parameters of the blood. This is clear from the rate of tumor growth in the primary site in the thigh, where aggressive growth of the tumor occurred in a similar manner to that of untreated animals. The results also indicate that the growth of tumor volume in the thigh of animals treated with either $4.5 \mathrm{~Hz}, 2 \mathrm{G}$ magnetic waves or with Methotrexate was minimal as compared to that of untreated group. Similar growth rate of tumor in the primary site for both Methotrexate and $4.5 \mathrm{~Hz}$ magnetic waves occurred. However, as a result of the toxic effects of chemotherapy (Mycek et al., 2000), a massive destruction of hepatocytes at the hepatic lobules occurred and supported by the findings of Zachariae, (1990), an observation, which didn't occur in animals, treated with magnetic waves. The effect of Methotrexate differs from the results obtained from using Methotrexate in combination with hydroxychloriquine for its antireheumatic effect as the tested drugs didn't show hepatic toxicity and this is due to using hydroxychloroquine that reduced the dose of methotrexate, thereby reducing its hepato-toxic effects (Shashikumar et al; 2010). In this study significant increase in total leukocyte count was observed in all tumor bearing groups. However this result is compatible with the significant increase in total leukocyte count that was observed by Nakamura et al; (2002) who used methotrexate on pulpal inflammation in rats.

The increase in total leukocyte count of tumor bearing mice treated with Methotrexate but no change was observed in plasma albumin level, these results were in compatible with the result of Rofe et al; (1994) using Methotrexate therapy in tumor bearing rats where there are decrease in total white cell count and decrease in plasma albumin level. This incompatibility may be due to difference in dose administrated, species of animals and environmental conditions. Also, non significant change in serum cholesterol level was noticed for tumor bearing mice in all treatments.

The formation of aggregates of tumor cells in the liver of group exposed to magnetic field in-addition to the formation of cells exhibiting multinucleoli are markers for the start of repair mechanism (Fadel et al., 2003). Further support to the present results(repair mechanism )was the finding of Truler et al; (1998,2000) who have studied the effectiveness of low level direct current in liver metastasis tumor growth, and Traitcheva et al; (2003) who have studied the lethal effect of extremely low frequency pulsed electromagnetic field on human cancer cells. More investigations are needed to confirm the afore-mentioned observations. The

Delta University for Science and Technology

Coastal International Road, Mansoura, Gamasa City, Dakahlia, Egypt

E-mail: dusj@deltauniv.edu.eg

Journal homepage: www.deltauniv.edu.eg/dusj 
results of the change in tumor size after exposure to magnetic waves are in agreement with other published data (Fadel et al., 2009).

\section{References}

1- Behari, J. (2010). Biological responses of mobile phone frequency exposure. Indian Journal of experimental biology; 48: 959981.

2- Cakir, D.U., Yokus, B., Akdag, M.Z., Mete, N. (2009). Alterations of hematological variations in rats exposed to extremely low frequency magnetic fields $(50 \mathrm{~Hz})$. Arch MedicalResearch; 40:352-356.

3- Culling, C.F. (1974). Histological and Histochemical techniques. 3rd edition, Butterworths and co., New York, London; 170-172.

4- Domenico, F. and Sergio, S. (2009). Biological effects of exposure to magnetic resonance imaging: an overview. BioMedical Engineering OnLine: 1-12

5- Elferchichi, M., Mercier, J., CoisyQuivy, M., Metz, L., Lajoix, A.D., Gross, R., Belguith, H., Abdelmelek, H., Sakly, M., Lambert, K., (2010). Effects of exposure to a 128-mT static magnetic field on glucose and lipid metabolism in serum andskeletal muscle of rats. Arch Medical Research; 41: 309-314.

6- Fadel, M.A. (1998). A new metabolic biomagnetic resonance model to describe the interaction of ELF-EM with biological system. Proceedings of International School on Theoretical Biophysics;

Moscow.p.p 213-234.

7- Fadel, M.A., Wael, S.M., Mostafa, R.M. (2003). Effect of $50 \mathrm{~Hz}, 0.2$ $\mathrm{mT}$ magnetic fields on $\mathrm{RBC}$ properties and heart functions of albino rats. Biolelectromagnetics; 24:535-545.

8- Fadel M.A., El Gebaly R. H., Aly A., Ibrahim F. (2005). Control of Ehrlich tumor growth by electromagnetic waves at resonance frequency in vivo. Electromagnetic Biological Medecine, 24: 9-12.

9- Fadel, M.A., (2006). Principle of biophysics, Introduction, Cairo University, Egypt. p.p. 74-75.

10-Fadel, M.A., EL Gebaly, R. H., Mohamed, A., Ahmed, M. R. (2009). Solid Ehrlich Tumor Growth Treatment by Magnetic Waves. Journal of medical engineering and technology UK.p.p.100-113.

11- Fadel, M.A., El-Gebaly, R., Aly, A., Sallam, A., Sarhan, O. and Eltohamy, H. (2010). Preventing of Ehrlich tumor metastasis in liver, Kidney and spleen by electromagnetic field. International Journal of the Physical Sciences; 5: 2057- 2065.

12-Feytching, M., Ahlbom, A., Kheifets, L. (2005): EMF and health. Annual Review Public health; 26:165-189.

13-Gerald, D., Tim V., Kroll, M.E., John, S. (2005). Childhood cancer in relation to distance from high voltage power lines in England and 
Wales: a case control study. Biomedical Journal; 330-1290.

14-Hashish, A.H., El Missery, M.A., Abdelkader, H.I. and Abou Saleh, R.H. (2008). Assessment of biological changes of continuous whole body exposure to static magnetic field and extremely low frequency electromagnetic fields in mice. Ecotoxicology and Environmental Safety; 71: 895-902.

15-Kheifets, 1., Bowman, J.D., Checkoway, H., Feytching, M., Harrington, J.M., Kavet, R. (2009). Future needs of occupational epidemiology of exteremly low frequency electric and magnetic fields. Occupational Environmental Medicine; 66:72-80.

16-Mycek, J.M., Harvey, A.R., Champe, C.P. (2000). Lippincott Illustrated Reviews. Chemotherapeutic Drugs-Anti Cancer drugs. New Jersy, United States.p.p.378-380.

17-Nakamura k. Yamasaki M. Nishigaki N. Iwama A. Imaizumi I. Nakamura H. Kameyama Y. (2002). Effect of methotrexate induced neutropenia on pulpal inflammation in rats. Journal Endod. 28:287-290.

18-Newell S., Sanson-Fisher R.W. (2000). Australian oncologists' selfreported knowledge and attitudes about non-traditional therapies used by cancer patients. Medical Journal Australia; 7: 110-113.

19- Ning S., Mcleod K., Abra R., Huang A.H., Hahn G.M. (1994). Hyperthermia induced doxorubicin release from long-circulating liposomes and enhanced their antitumor efficacy. International Journal Radiation Oncology, Biology, Physiology; 29: 827-834.

20-Rofe, A.M., Bourgeois, C.S., Washington, J,M, Philcoxm J.C., Coyle P. (1994). Metabolic consequences of methotrexate therapy in tumour-bearing rats. Immunology Cell Biology.; 72:4348.

21- Shashikumar, N.S., Shivamurthy, M.C., Chandrashekara, S. Evaluation of efficacy of combination of methotrexate and hydroxychloroquine with leflunomide in active rheumatoid arthritis. Indian journal of pharmacology; 42 : 358-361

22- Traitcheva, N., Angelova, P., Radeva, M., Berg, H. (2003). ELF fields and photooxidation yielding lethal effects on cancer cells. Bioelectromagnetics, 24:148-50.

23-Turler, A., Schaefer, H., Schaefer, N., Maintz, D., Wagner, M., Qiao, J., Hoelscher, A. (2000). Local treatment of hepatic metastases with lowlevel direct electric current: experimental results. Scand. J. Gastroenterol; 35: 322-328.

24- Turler, A., Schafer, H., Schafer, N., Fischbach, R., Wagner, M., Qiao, J.C., Holscher, A.H. (1998). Pilot study of effectiveness of electrotherapy in the experimental liver metastasis model. Langenbecks Arch Chir Suppl Kongressbd. 115:611-614. 
25-Tu, A.T.and Giltner, J.B. (1974). Cytotoxic effects of snake venoms on KB and Yoshida sarcoma cells. Research Community Chemical Pathology and Pharmacology. 9: 783-786.

26- Young, D.S. (2000). Effects of drugs on clinical laboratory tests, 5th edition AACC Press, 967-975.

27-Zachariae, H. (1990). Methotrexate side-effects. The British journal of dermatology; 13, 122- 127. 